\title{
Una armada de galeras para la Carrera de Indias: el Mediterráneo y el comercio colonial en tiempos de Felipe II $^{1}$
}

por

\author{
José Manuel Díaz Blanco \\ Universidad de Huelva
}

\begin{abstract}
Este artículo intenta vincular la reorganización de la Carrera de Indias en la década de 1560 y los «seis últimos años de la supremacía turca» en el Mediterráneo (1559-1665) estudiando la historia de una armada de galeras casi olvidada. El análisis de los documentos relativos a esta armada en el Archivo General de Indias permite concluir que la guerra mediterránea entre España y el Imperio Otomano fue una de las causas para la creación del sistema de convoyes de la Carrera.

Palabras Clave: Monarquía Hispánica (Felipe II); Imperio Otomano (siglo XVI); Carrera de Indias; Mediterráneo; galeras.
\end{abstract}

El enfrentamiento de las potencias cristianas contra el Imperio Otomano y sus estados satélites alcanzó el punto álgido durante la primera mitad del reinado de Felipe II. Después de la paz de Cateau-Cambrésis (1559), España se vio relativamente libre de las tensiones internas de la Cristiandad y se lanzó al Mediterráneo para enfrentarse al Turco. El desastre de Djerba (1560) significó un revés durísimo, pero también fue una enseñanza útil. La Monarquía Hispánica y las demás estados cristianos tomaron consciencia de la necesidad de reaccionar frente al poder osmanlí. Así llegaron las victoriosas defensas de Orán (1563) y Malta (1565), la ocupación del Peñón de Vélez de la Gomera (1564) y el sonado triunfo en la batalla de Lepanto (1571). La formulación historiográfica más conocida de estos acontecimientos se encuen-

${ }^{1}$ Este trabajo se ha realizado con un contrato del programa Juan de la Cierva del Ministerio de Economía y Competitividad de España, expediente JCI-2011-11153. Agradezco al Dr. Manuel Lomás Cortés su generosa ayuda para mejorar sustancialmente este texto. 
tra en el Mediterráneo de Fernand Braudel. Según el historiador francés, el período comprendido entre 1559 y 1565 debe ser conocido como el de «los seis últimos años de la supremacía turca». Pero sin olvidar algo, que aquél fue «el momento culminante del poderío otomano. Es decir, que el Islam comienza a declinar en 1560». El cambio se debió a la respuesta cristiana, sobre todo española. Aquellos últimos años de la supremacía turca fueron también los de la «recuperación hispánica» ${ }^{2}$.

Paralelamente, se ha situado en la década de 1560 el principal hito formativo del sistema de convoyes sobre el que se sustentó la Carrera de Indias, desde entonces hasta el siglo XVIII. En 1561 y 1564 se publicaron las dos provisiones que establecieron que ninguna nao viajase a América sin ir en conserva y que todos los años saliesen de la Baja Andalucía dos flotas y una armada. En opinión de Federico de Castro y Bravo, «hasta 1561 no se estableció el conocido sistema del envío periódico de dos flotas a Nueva España y Tierra Firme» ${ }^{3}$. En la de Clarence H. Haring, «fue por los años de 1564 a 1566 cuando se dio a la navegación de las Indias la organización que mantuvo con pocas variantes en toda la época de los Habsburgos» $\rangle^{4}$. Según Antonio García-Baquero, «fue entre 1561 y 1566 cuando se sentaron, definitivamente, las bases por las que habría de regirse en el futuro este sistema de navegación» ${ }^{5}$. Para Esteban Mira Caballos, «en 1561-1564 apareció perfectamente legislado y detallado un modelo naval que duró más de dos siglos» ${ }^{6}$.

La coincidencia cronológica entre la fase más crítica de la guerra en el Mediterráneo y la organización del sistema de flotas y armadas en la Carrera es bastante notable. Ambos procesos tuvieron lugar en aquellos «seis últimos años de la supremacía turca», entre 1559 y 1565. ¿Existió alguna relación entre ellos? La historiografía no parece haberlo detectado. En opinión de David Goodman, puede hablarse de una «espectacular transformación de España en una potencia naval a fines del siglo XVI». Esta conversión «tuvo su origen en una serie de procesos políticos» entre los que el primero fue el desastre de Djerba. Aquel suceso traumático «convenció a Felipe II de que

2 Braudel, 2005, II, tercera parte, cap. 2 y especialmente: 449. La historiografía referente a este proceso de «recuperación hispánica» es amplísima. Véase, por ejemplo, Thompson, 1981; García Hernán, 1995; Fenicia, 2003 o Favarò, 2009. En otros estados mediterráneos también se desarrollaron las fuerzas navales: Lane, 1973; Glete, 2002; Lo Basso, 2003. Estos dos últimos autores explican el caso español y lo insertan dentro de una perspectiva internacional, cada uno desde sus respectivos puntos de vista.

3 Castro y Bravo, 1927: 50.

4 Haring, 1979: 258-259.

5 García-Baquero González, 1992: 90.

6 Mira Caballos, 2006: 10. 
era esencial una flota más poderosa para la protección de las posesiones españolas en el Mediterráneo». Y la construyó. Fue la que posibilitó la «reacción hispana» anunciada por Braudel con su sucesión de victorias navales. Pero, según Goodman, los ecos de Djerba sólo sonaron en el Mediterráneo. El desarrollo de la navegación oceánica habría sido consecuencia del segundo proceso político destacado por el historiador inglés: el giro atlantista de la vida europea. El desplazamiento del eje de gravedad del Mediterráneo al Atlántico se habría producido en la década de 1570 y una de sus causas fundamentales habría sido la «creciente necesidad de defender el imperio americano», para cuyo comercio "existía ya un elaborado sistema de convoyes» hacia 15647. Ninguna relación, pues, con los acontecimientos del Mediterráneo.

La hipótesis de la conexión tampoco se encuentra presente en los últimos trabajos sobre la navegación y los sistemas defensivos de la Carrera de Indias en el siglo XVI, debidos principalmente a Esteban Mira Caballos. Según su reconstrucción de los acontecimientos, dichos sistemas defensivos nacieron con la gestación de una Armada Guardacostas de Andalucía, que fue mucho más que una unidad de carácter regional, a pesar de lo que pueda sugerir su nombre. Durante la primera mitad del siglo XVI, la principal responsabilidad en la protección del comercio colonial recayó sobre esta escuadra, formada en 1521 y operativa, al menos, hasta 1550 aproximadamente. Desde entonces, aunque pueden encontrarse algunos rastros sobre su continuidad en fechas posteriores, cayó en decadencia y desapareció, porque quedó obsoleta desde la década de 1560 ante la consolidación de la Armada de la Guarda de la Carrera de Indias dentro del sistema de flotas y armadas ${ }^{8}$. Mira Caballos ha señalado que el factor que impulsó el desarrollo de los sistemas defensivos de la Carrera fue la presión pirática y corsaria proveniente de los rivales europeos de España, especialmente Francia y que la culminación de su estructura debe rastrearse en una colección de propuestas hechas por marinos de enorme talla, entre los cuales Pedro Menéndez de Avilés redactó en 1556 un memorial que puede considerarse el documento inspirador del sistema de convoyes de $1561^{9}$. Esta explicación, aunque profundamente renovadora, también es puramente atlantista y tampoco guarda conexiones con los acontecimientos del Mediterráneo.

7 Goodman, 1997: 19-30.

8 Mira Caballos, 1998.

9 Mira Caballos, 2002: 39-57; 2003: 7-20; 2006: 7-24. Para otro ámbito, como es el valenciano, puede consultarse Pardo Molero, 2001: 289-430. 
En efecto, ha podido demostrarse que la amenaza europea fue el principal acicate para el desarrollo naval de la Carrera de Indias durante la primera mitad del siglo XVI, decenios de máxima rivalidad entre los Habsburgo y los Valois. Puede documentarse que muchas de las innovaciones registradas en la década de 1560 siguieron teniendo su origen en este factor. A pesar del relativo retraimiento de las grandes guerras dinásticas después de Cateau-Cambrésis, el corso y la piratería fueron todavía un desafío que requería mejoras constantes para contrarrestar sus efectos. De hecho, puede demostrarse que el establecimiento del ritmo bianual de las flotas de Indias surgió directamente de un choque contra navíos franceses ocurrido en 1561. Sin embargo, por aquellos mismos años también hubo enfrentamientos contra navíos ingleses y escoceses ${ }^{10}$. Y con navíos turco-berberiscos. En realidad, en no pocos momentos, el enemigo más temido fue el corso norteafricano. Lo desvelan testimonios de la época como la narración de la salida de la flota de Pedro Menéndez en 1562 que la Casa de la Contratación envió a Felipe II: «Salió la flota de que va por general Pero Menéndez [...], que por todos eran más de çient nauíos y que yrían juntos y en conserua hasta estar desviados del peligro de los Turcos» ${ }^{11}$.

La percepción del peligro turco-berberisco también estuvo en el origen de las innovaciones navales de los años 60, aunque la historiografía no lo haya reconocido así. ¿Por qué? Posiblemente por la presunción de que el sistema de convoyes nació en 1561 perfectamente definido, circunstancia que pretende discutirse como errónea en este trabajo. Establecer la definición del modelo clásico de dos flotas y una armada de la Carrera entre 1561 y 1564 ó 1566 no es sino proyectar sobre los años iniciales de su proceso formativo la morfología que no adquiriría hasta su momento conclusivo, cerca de 1570. Es empezar por el final. En realidad, el sistema de navegación de comienzos de los 60 fue concebido de un modo distinto, porque también tenía prevista la inclusión entre sus sistemas defensivos de una armada de galeras, que no fue sino la última prorrogación de la Armada Guardacostas de Andalucía, a la que la historiografía ha tenido poco en cuenta. Aunque el ritmo bianual de las flotas también puede atribuirse en parte al peligro norteafricano, el principal elemento vinculado a la guerra en el Mediterráneo dentro del sistema de navegación de los años 60 fue esta armada. Al haber sido olvidada, se minusvaloró también el factor norteafricano.

10 Archivo General de Indias, Sevilla (AGI), Indiferente General (IG), leg. 1.966, lib. 14, fol. 153v: «en la Carrera de las Yndias andan algunos nauíos corsarios, ansý franceses como ingleses y escoceses».

11 AGI, Contratación, leg. 5.167. 
En efecto, esta armada de galeras ha pasado muy desapercibida. Además de algunas referencias aisladas ${ }^{12}$, sólo Eufemio Lorenzo Sanz le ha dedicado una atención detenida ${ }^{13}$. Sin embargo, para los hombres del comercio tuvo una enorme importancia, según demuestra el primer inventario del archivo del Consulado, confeccionado entre 1566 y 1589. Muchos de sus registros se vinculan directamente a la armada y a diferentes aspectos de su gestión ${ }^{14}$. La meticulosa conservación de esta documentación en el archivo consular no deja lugar a engaño. La armada de galeras fue uno de los asuntos a los que el Consulado dedicó más atención durante la década de 1560. Es normal. El mismo Consulado solicitó su creación como complemento militar de las dos flotas anuales recientemente creadas. Para muchos de los mercaderes de entonces, debió de ser el principal mecanismo de defensa del comercio atlántico.

Así pues, escribir la historia de esta armada de galeras no se reduce sólo al gratificante placer de rescatar del olvido acontecimientos que fueron importantes en un tiempo pasado. Su conocimiento permite formular varias conclusiones:

1. El sistema de convoyes no nació perfectamente definido en 1561.

No se redujo desde el comienzo a una combinación de dos flotas de Nueva España y Tierra Firme, protegidas por una Armada de la Guarda de la Carrera de Indias. La disposición de 1561 se complementó con una real provisión de 1562, prácticamente ignorada hasta la fecha, mediante la cual se prorrogó por última vez la Armada de la Guarda de las Costas de Andalucía, una escuadra de ocho galeras cuya función principal fue proteger el comercio indiano del corso norteafricano. Ésa fue la verdadera morfología original del sistema, que no perdió hasta que la armada de galeras desapareció definitivamente, allá por 1568. Fue entonces, frisando el 1570, cuando se impuso por

12 Chaunu, 1955: 28-29, que creyó que la escuadra se vio frustrada a causa de los naufragios de galeras de 1562 y fue sustituida en su labor por la armada de Pedro de las Roelas. Olesa Muñido, 1968: 507. Thompson, 1981: 206.

13 Lorenzo Sanz, 1986, II: 352-354. Ocupa un epígrafe de casi dos páginas basado en documentación de la sección Estado del Archivo General de Simancas (AGS), con correspondencia entre Felipe II y el Consulado.

14 AGI, Consulados, lib. 46. De los 31 registros correspondientes a la documentación que el Consulado acumuló en su archivo entre 1543 y 1566, cuando se empezó a inventariar, 13 estaban dedicados a la armada de galeras y su avería, es decir, el 42\%. De los 110 inventariados hasta 1589 , lo estaban 23 , el $21 \%$. El porcentaje es muy notable, teniendo en cuenta que la armada sirvió durante un tramo pequeño de todo el período que cubre el inventario. Además, debe tenerse presente que en otros registros genéricos -de correspondencia del Consulado, de libros de acuerdos o de cédulas y órdenes del rey- debió de haber documentación relativa a la materia. 
vez definitiva el sistema de navegación puramente atlántico que se expone generalmente en los estudios sobre la Carrera.

2. La guerra en el Mediterráneo estuvo muy presente en la formación del nuevo sistema de navegación.

En realidad, eso podría afirmarse si sólo se analizase el modelo de las dos flotas anuales, pero se hace completamente evidente repasando los avatares de la armada de galeras. Ciertamente, el factor norteafricano dejó de jugar un papel relevante en poco tiempo. Hacia 1568, la armada de galeras desapareció por sus propios problemas internos, aunque la guerra en el Mediterráneo aún mantenía mucha pujanza ${ }^{15}$. Después de la década de 1570 , tras el giro atlantista de la política europea, no habría tenido apenas sentido.

\section{Miedo en El MAR: LA CREACIÓN DE LA ARMADA DE GALERAS}

El análisis de María J. Rodríguez Salgado sobre la década de 1550 en la Monarquía Hispánica demuestra que la principal prioridad que empujó a Felipe II a regresar a Castilla en 1559 fueron los apuros económicos de la Real Hacienda ${ }^{16}$. Los recursos fiscales castellanos fueron desde entonces la piedra miliar de la política internacional de la Monarquía ${ }^{17}$. Uno de los más apreciados eran los tesoros procedentes de las Indias. Los que correspondían a la Real Hacienda y los de los particulares, de los que podía echarse mano en caso de necesidad ${ }^{18}$. De hecho, en aquellos años trascendentales de 1550 se registró una de las fases de incautaciones más voraces de la Casa de Austria, incluso sin deflactar los valores nominales de las sumas ${ }^{19}$.

La importancia capital de los tesoros americanos en la Hacienda castellana ponía sobre el tapete la necesidad de garantizar su seguridad durante el largo periplo oceánico. Los mares no eran seguros. Lo denunciaban los mercaderes y lo reconocía el Gobierno. La maniobra de unos pequeños navíos franceses sobre naos procedentes de Santo Domingo fue la gota que colmó el vaso en 1561. Según la narración que el Consulado hizo al rey sobre el incidente, los intrusos entraron en Sanlúcar de Barrameda el 8 de junio.

15 Se desarrollaba justo entonces la guerra de las Alpujarras, que no dejó de tener una cierta dimensión naval: Benafri, 2011.

16 Rodríguez Salgado, 1992.

17 Modesto Ulloa, 1986.

18 Hamilton, 2000. Lorenzo Sanz, 1986, II, cap. 9.

19 Véanse la cuantificación y análisis de Rodríguez Salgado, 1992. Y, sobre todo, Lorenzo Sanz, 1986, II, cap. 5. 
Ninguno de sus barcos alcanzaba más de setenta toneladas, pero se bastaron para atacar a las naos españolas y robarles «todo el oro, plata y perlas q[ue] en ellas venía, q[ue] sería buena suma y toda el artillería de bronze y muniçiones de arcabuzes, ballestas y coseletes». No era un accidente anecdótico, pues por los mismos días se vieron otros barcos franceses en las Azores y en el cabo de San Vicente. Para los consulares, la conclusión era evidente: «está esta Carrera de las Yndias, así a la yda como a la venida, mui peligrosa y llena de cosarios». Era necesario reaccionar. En primera instancia suplicaron al monarca que intentase pactar medidas punitivas contra los corsarios con la monarquía francesa, con la que entonces se hallaba en paz. Aunque, por supuesto, entendían que sería más práctico elaborar mecanismos propios de defensa que depender de la dudosa colaboración exterior. Lo que se les ocurrió no debe sonar extraño a nadie familiarizado con el comercio colonial. A petición de toda la Universidad de Mercaderes, suplicaron a Felipe II que «mandase dar orden como vaian dos flotas a las Yndias en el año la vna por agosto y la otra por hen[er]..$^{\circ}$ y antes ni después de estas flotas no pueda salir ning[un]. ${ }^{a}$ nao, por q[ue] vaian todas juntas llevando su capitán y almirante cada flota» ${ }^{20}$.

La súplica del Consulado fue atendida. A raíz de estos avisos, se publicó la famosa provisión de 16 de julio de 1561. Su contenido es sobradamente conocido, pero resultará interesante recordar su parte expositiva, que explica las circunstancias que justificaron la nueva normativa de navegación:

Después que [las naos] çessaron de yr en flota como solían yr, an tomado cosarios algunos nauíos que venían de las d[ic]has $n$ [uest]ras Yndias y si no se diese orden de manera que los $\mathrm{d}[\mathrm{ic}]$ hos naúos pudiesen nauegar con seguridad, cada día tomarían los d[ic]hos cosarios cantidad de haziendas de las que se lleuan a las $\mathrm{d}\left[\right.$ ic] has $\mathrm{n}\left[\right.$ uest]ras Yndias y el oro y plata que dellas viniese ${ }^{21}$.

El documento se refiere a los acontecimientos denunciados recientemente en la correspondencia consular. Sin embargo, se ha evitado cualquier referencia precisa hacia el origen de los corsarios. No se habla de corsarios franceses, como hacían las cartas sevillanas, sino de corsarios en general. El cambio no es casual. La ley, significativamente, no hacía distinciones.

${ }^{20}$ El Consulado a Felipe II, Sevilla, 4 de julio de 1561, AGI, Consulados, leg. 48, fol. 113. En el mismo volumen se encuentra más documentación sobre el tema. La Casa de la Contratación avaló la petición de los mercaderes: la Casa a Felipe II, Sevilla, 4 de julio de 1561, AGI, Contratación, leg. 5.167, folios 94v-97v.

${ }^{21}$ Real provisión, Madrid, 16 de julio de 1561, AGI, IG, leg. 1.966, lib. 14, folios 35v-37v. 
Evidentemente, el rey y sus ministros sabían que el peligro corsario era internacional, aunque el precipitante inmediato del nuevo orden hubiese sido el ataque francés a las naos de Santo Domingo. Podrían haberlo protagonizado corsarios de diferente origen. De hecho, en ese escenario global el corso norteafricano jugaba un papel esencial22. En mayo de 1561, pocos meses antes de la publicación de la provisión, el Consulado escribió a su representante en la isla Terceira para informar de la presencia de «çierta armada turquesca q[ue] avía venido a çercar a Orán y q[ue] avían abaxado a desenbocar al estrecho más de 20 velas, galeras y galeotas y q[ue] estaban rep[ar]tidas junto a Cádiz y S[an]lúcar a fin de hazer alguna presa en las naos q[ue] vienen de Yndias» ${ }^{23}$. Esta presión turco-berberisca en el mar fue tan intensa que requirió medidas específicas. Necesitó la creación de una armada de galeras complementaria a la Armada de la Carrera de Indias ${ }^{24}$. Esta formación no fue otra cosa que la prorrogación de la Armada Guardacostas de Andalucía que había funcionado entre 1521 y 1550, que en los años 60 quedó adherida al nuevo sistema de flotas y armadas. Por tanto, aquel sistema no nació plenamente definido. Sus sistemas defensivos nacieron con un carácter mixto que no perdieron hasta fecha cercana a 1570, cuando la Armada Guardacostas parece extinguirse definitivamente.

La gestación de la armada de galeras fue también una idea del Consulado. A fines de año preparó un documento donde se contabilizaban los ataques efectuados a barcos españoles desde Vélez de la Gomera entre los meses de agosto y octubre. La información que el Consulado tenía a su disposición era alarmante, porque suponía que el «rey» de Argel, recién llegado de Turquía, había mandado llamar al alcaide de Vélez y le había dado más galeras «para que ande en estas costas del Andaluzía a rrobar y esperar las naos de Yndias que van y vienen, para las tomar, ques a lo que todos pretenden $\rangle^{25}$. Esta información no podía ser ignorada. Demandaba soluciones y la que el Consulado tenía en la cabeza era la armada de galeras, según se desprende de la correspondencia que empezó a enviar, ya en enero de $1562^{26}$. Los represen-

22 Hess, 1978.

23 El Consulado a Hernán García Jacques, Sevilla, 6 de mayo de 1561, AGI, Consulados, lib. 48 , fol. 97.

24 El término Armada de la Guarda de la Carrera de Indias no apareció hasta 1575 ó 1576, aproximadamente (Goodman, 1997: 22), aunque armadas de este tipo las hubo antes de entonces y antes de la provisión de 1561 .

25 AGI, Consulados, lib. 48, folios 139r-140r. Presumiblemente, el documento parece referirse a Dragut, famoso personaje sobre quien pueden encontrarse referencias en Pardo Molero, 2001.

26 Ibidem, folios $141 \mathrm{v}-142 \mathrm{r}$. 
tantes y aliados del Consulado en la corte -Hernando de la Fuente, Gaspar Jerónimo del Castillo, el correo mayor Rodrigo de Jerez y don Álvaro de Bazán (que luego sería el general de la escuadra)- tendrían que informar en los Consejos de Guerra e Indias y, a ser posible, ante el propio Felipe II. Desde Madrid fueron llegando rumores positivos, aunque la respuesta oficial no lo fue tanto. La Monarquía, como cabía esperar, dio su visto bueno al apresto de la armada, pero evitó implicarse excesivamente en su financiación, como el Consulado parecía haber esperado ${ }^{27}$.

La Universidad de Mercaderes se reunió de inmediato. Todo el mundo era consciente de que se necesitaba la armada de galeras, pero no había consenso respecto a los pagos. En una carta al secretario Francisco de Eraso, el prior y cónsules respondieron airadamente, recordando al rey lo que era obligación suya y lo que no:

$\mathrm{Su}$ M. a de hazer m[erced] a esta Vniuersidad y quisiéramos mucho questa Vniuersidad tuviera posibilidad para seruir a su M. conforme a la voluntad que para hazerlo tiene, pero la estrechura no a dado lugar a poder alargarse a más y su Magd se deue de tener por bien seruido, pues teniendo obligaçión de guardarnos estas costas a su costa, lo hazemos a costa de averías de más de que los que tractan en las Yndias pagan otras averías de yda y venida para el armada q[ue] va y viene a las d[ic]has Yndias y asimesmo pagan el almoxarifasgo aquí en Seui[11]. ${ }^{a}$ de la salida y otro de la entrada en las Yndias y seguros y otras eçesivas costas, en que se consume la mayor parte de las haziendas ${ }^{28}$.

$\mathrm{Su}$ actitud no resulta extraña. Los mercaderes eran reacios a sacrificar partes tan sustanciales de sus ganancias pagando impuestos. Algún tiempo antes, sólo dos semanas después de haber suplicado la creación del sistema bianual de flotas, protestaron que se aprestase la Armada de la Carrera para proteger a los mercantes que venían de Nombre de Dios. Este comportamiento puede parecer incoherente, pero la razón que lo explica es sencilla. La Armada tendría que financiarse «a costa de lo q[ue] en ellas [las naos] biniere» ${ }^{29}$. Es decir, había que pagar la avería.

La armada de galeras quedó definitivamente aprobada mediante una real provisión de 26 de abril de 1562. El documento ratificaba que debía crearse una armada para proteger el comercio indiano de los corsarios norteafricanos y resolvía el espinoso tema de la financiación legalizando una nueva avería, adicional a la que financiaba la Armada de la Carrera de Indias, que no sería

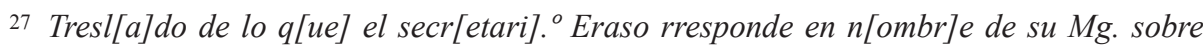
las galeras, Madrid, 7 de marzo de 1562, Ibidem, folios 150r-152r.

28 Ibidem, fol. 156.

${ }^{29}$ El Consulado a Felipe II, Sevilla, 18 de julio de 1561, Ibidem, folios 117-118. 
pagadera sólo por los comerciantes de la Carrera de Indias, sino también por los de Levante y Poniente y pueblos de la $\operatorname{costa}^{30}$ :

Lo que se gastare en armar las d[ic] has ocho galeras y en el mantenimiento e sustentaçión dellas se pague por auerías del oro e plata e perlas e reales e otras mercaderías que vinieren de las Yndias e de los cascos de los nabíos que se cargaren y vinieren e fueren a ellas asý de yda como de venida e qualquier puerto que se cargaren e descargaren de leuante e poniente e de Canaria y de los Açores e de las islas de la Madera e Berbería a las ciudades de Seuilla e Málaga y Cádiz e Jerez de la Frontera y de las villas del Puerto de Santa María e Sanlúcar de Barrameda e Gibraltar y Rota e Chipiona e a los puertos del condado de Niebla y Ayamonte e Lepe e La Redondela, aunque sea el d[ic]ho oro y plata e perlas y mercaderías e navíos que asý ovieren de contribuyr en el gasto e sustentaçión de las d[ic] has galeras n[uest]ro o de qualesquier personas previlegiadas o por previlegiar, pues que se haze para guarda de todos e que tanbién se cobre la d[ic]ha avería p[or] el $\mathrm{d}[\mathrm{ic}]$ ho efeto de todas las mercaderías que partieren de los $\mathrm{d}[\mathrm{ic}] \mathrm{hos}$ puertos para las $\mathrm{d}[\mathrm{ic}]$ has partes o de los nabíos que las traxeren e lleuaren ${ }^{31}$.

Como puede suponerse, esta decisión tuvo una amplia contestación social. Si la armada de galeras estaría destinada a proteger el comercio colonial, ¿por qué tenían que contribuir a su sostenimiento personas que ninguna relación tenían ni sacaban ningún beneficio de él?

En efecto, la decisión no fue bien recibida en Andalucía ${ }^{32}$. En muchos puntos de la región sonaron voces discrepantes contra las galeras o, por mejor decir, contra su financiación a través de una nueva avería. Nadie quería tributar un impuesto adicional sobre los demás gravámenes aduaneros que se cobraban en todos los puertos. Las protestas más firmes se oyeron en Sanlúcar de Barrameda, donde la Casa de Medina Sidonia expresó una rotunda disconformidad respecto al proyecto de la Corona y el Consulado ${ }^{33}$. Los Pérez de Guzmán no tenían ningún interés en la Carrera de Indias por aquel entonces y pese a la falta de beneficio, quería causárseles el perjuicio de aumentar la

30 Aquí hay una línea de continuidad clara entre la armada de galeras y las anteriores armadas guardacostas de Andalucía, que también se financiaron mediante una avería específica: Mira Caballos, 1998: 40-41.

${ }^{31}$ AGI, Justicia, leg. 1.150, n. $^{\circ} 1$, r. 2, s.f.

32 En este aspecto la armada de galeras no se diferenció de las anteriores armadas guardacostas de Andalucía, cuya financiación también suscitó protestas. Mira Caballos, 1998: 42-43, que destaca la animadversión expresada por los mercaderes y los grandes títulos nobiliarios.

33 En 1562 el ducado de Medina Sidonia pertenecía a un niño, Alonso Pérez de Guzmán, el Bueno, VII duque, menor de edad tutelado por doña Leonor Manrique de Sotomayor, IX condesa de Niebla. En algunas de sus protestas fue secundada por doña Teresa de Zúñiga y Manrique de Lara, duquesa de Béjar, que también era marquesa de Ayamonte. 
imposición sobre mercancías que, en consecuencia, se encarecerían y perderían competitividad en el mercado. Se lamentaban sobre todo por los atunes que se pescaban en sus almadrabas del estrecho de Gibraltar. Tenían el agravante de que hasta la fecha habían estado exentos de contribución tributaria, puesto que eran un privilegio que les había concedido y renovado la Corona en virtud a los grandes servicios realizados por la Casa. A causa de todo ello, reclamaban una rectificación drástica de la medida ${ }^{34}$.

Los pequeños y medianos municipios costeros también protestaron la medida. Los concejos de Cádiz, Sanlúcar de Barrameda, Vejer de la Frontera, Huelva, San Juan del Puerto, Conil, Málaga, Puerto Real ${ }^{35}$ y Lepe protestaron con argumentos parecidos a los que habían esgrimido los Medina Sidonia, a los que sumaron de vez en cuando otros más específicos, relativos a las circunstancias particulares de cada uno de ellos. Algunos eran auténticos, otros eran simples excusas. El problema de fondo era que nadie entendía ni quería aceptar por qué debía pagarse una nueva figura fiscal destinada a financiar una armada de la que no se beneficiaría nadie que no participara en la Carrera de Indias, a no ser de forma muy indirecta y ocasional. Se temían los daños y perjuicios del incremento tributario y no se quería asumir que fuesen a cambio de nada o muy poco ${ }^{36}$.

Finalmente, los tratantes en Indias sevillanos protestaron también. Nada de lo que asombrarse, conociendo los preliminares de la negociación. Los comerciantes habían temido las consecuencias del corso sobre el transporte de mercancías, pero no les agradaba la solución que Felipe II había encontrado al problema. Les hacía pagar demasiado, más de lo que les parecía razonable. Se enojaron al saber que, a falta de una, habría que costear una segunda avería para mantener las galeras. «No es justo [...] pagar dos auerías, vna de las galeras y otra del armada». Los comerciantes protestaban por la excesiva carga fiscal que suponía un sistema militar doble, compuesto de armada de flotas y armada guardacostas. Era redundante y muy caro. Juan Gutiérrez Tello y el Consulado, a los que se había designado como directores de la nueva estructura fiscal, no dejaron de representar la opinión de sus protegidos. Hicieron saber su descontento al monarca y lo unieron a la insatisfacción general que había generado la nueva avería de galeras: «todo el pueblo y nauegantes contradizen la $\mathrm{d}[\mathrm{ic}]$ ha cobrança con grandes querellas y [...] les sobra rrazón».

34 Respecto a las cambiantes relaciones políticas entre la Corona y los Medina Sidonia en los siglos XVI y XVII, Salas Almela, 2008.

35 Puerto Real pretendió defenderse aduciendo los privilegios reales que había recibido desde tiempos de los Reyes Católicos. Sobre este tema, Iglesias Rodríguez, 2003.

${ }^{36}$ AGI, Justicia, legajos 1.150, n. $^{\circ} 1$, r. $2 ; 783$, n. $^{\circ} 2$ y 785, n. $^{\circ} 2$. 
El Gobierno titubeó ante una oposición tan abierta y extensa. Recordó a la diputación que le había ordenado cobrar la avería en virtud de las circunstancias, «entendíase quándo y cómo conviniere», y que no se había buscado en ningún momento agraviar a nadie. Por tanto, ordenó que de momento dejase de cobrarse la avería, que se devolviese lo que se había ingresado y que no se reanudase la recaudación mientras no hubiese nuevo aviso. Hasta la segunda quincena de junio de 1562 se cobraron 111.288 maravedíes en concepto de avería, de los que se devolvió casi todo, 102.202 maravedíes, no quedando en caja más que una cantidad irrisoria de $9.086^{37}$. Sin embargo, la suspensión duró poco. Puede sospecharse -aunque no lo dijeran explícitamente, porque dañaba al colectivo que supuestamente debían defender- que Gutiérrez Tello y el Consulado no se resignaban a renunciar a los privilegios y ventajas que, como se verá, les confería el asiento de la armada. La Corona aprovechó los argumentos que ellos mismos le brindaron para reanudar el apresto de una armada que debería garantizar la seguridad de las remesas de metales preciosos, fundamentales para la Real Hacienda. La oposición social fue al fin desatendida y desechada. La armada de galeras estaba presta para comenzar a actuar en la costa andaluza ${ }^{38}$.

\section{LA AVERÍA Y LA ARMADA DE GALERAS}

La puesta en marcha de aquel proyecto creó una doble estructura institucional. En primer lugar, nació una estructura fiscal que consiguió la financiación necesaria para abastecer la nueva armada. Y, por supuesto, se creó una estructura militar que fue la propia escuadra, formada por ocho galeras y una fragata. La conexión entre ambas y el funcionamiento individual de cada una de ellas fueron las claves que permitieron contar con un servicio especializado de defensa costera en Andalucía a partir de 1562.

La estructura fiscal giró en torno al cobro de un nuevo derecho, la avería de galeras, que, una vez fracasados los intentos iniciales de resistencia, hubo de cobrarse en los puertos comprendidos entre el cabo de San Vicente y Má$\operatorname{laga}^{39}$. Su administración se confió a una diputación formada por Juan Gutié-

37 AGI, Contaduría, leg. 421, fol. 117r.

38 Real cédula, Madrid, 11 de julio de 1562, Ibidem, folios 89-90.

39 El modelo de financiación fue tremendamente particular dentro del mundo de las galeras. Las galeras se financiaban a través de las Tres Gracias, norma ante la cual este caso significa una de las escasas excepciones conocidas, si no la única. Thompson, 1981: 103. 
rrez Tello, tesorero de la Casa de la Contratación, y el prior y cónsules de la Universidad de Mercaderes ${ }^{40}$. El asiento de 1562 lo estableció así:

Primeramente, q[ue] Juan Gutiérrez Tello, n[uest]ro thesorero de la Casa de la Contrataçión de Seuilla en n[uest]ro nonbre juntamente con el prior e cónsules de la Uniuersydad de los Mercaderes de la d[ic]ha çiudad de Seuilla tengan cargo de proueer lo que conviniere para armar e poner en horden las $\mathrm{d}[\mathrm{ic}] \mathrm{has}$ galeras e fragata e para la sustentaçión dellas conforme a lo que está asentado y capitulado con el d[ic]ho prior y cónsules e para ello gasten lo que fuere nesçesario de las averías que se cobraren.

De esta concesión básica se derivaban otras. A saber: cierta libertad para conseguir la financiación que necesitasen las galeras, la discutida jurisdicción sobre casi todos los movimientos comerciales de los puertos andaluces, el reparto de las presas que se tomasen, capacidad para pedir prestado y endeudarse durante los primeros meses... Obviamente, la diputación también estaría sujeta a varias obligaciones: la conservación de lo recaudado en un arca de tres llaves puesto en la Casa de la Contratación, el pago de los salarios de la gente de mar y guerra, la provisión de artillería o el nombramiento de un escribano para que apuntase todas las cuentas. Finalmente, se le reservaba un lugar de consideración en las futuras decisiones sobre la prorrogación o desmantelamiento de las galeras. Estaba previsto que la armada sirviese durante tres años, pero la diputación podría solicitar que dejase de hacerlo antes o que siguiese funcionando después de transcurrido el plazo. En todos los casos su opinión sería tenida en cuenta, aunque obviamente el Gobierno se reservó la última palabra en el asunto ${ }^{41}$.

Subordinado a esta diputación, hubo un equipo ejecutivo que se dedicaba a hacer cumplir las decisiones tomadas por Gutiérrez Tello y el Consulado. Se trataba de una red piramidal de receptorías de avería cuya base se extendía por diversas localidades andaluzas y cuyo vértice se encontraba en Sevilla. Esta receptoría central recaudaba la avería específica de la capital y recibía, salvo excepciones, la recaudación de las receptorías locales y regionales. Después efectuaba los pagos necesarios para la provisión de las galeras, de-

40 En esto se percibe otro punto en común entre la armada de galeras y las anteriores armadas guardacostas de Andalucía, que también fueron gobernadas por un juez de averías procedente de la Casa y por una diputación del comercio, entonces aún no constituido en Consulado: Mira Caballos, 1998: 36-40. El paralelismo es tal que entre 1536 y 1549 fue juez Francisco Tello, padre de Juan Gutiérrez Tello y su antecesor en la tesorería de la Casa de la Contratación: Schäfer, 2003, I: 363.

41 AGI, Contaduría, leg. 421, folios 72-75. 
bidamente autorizados por libranza previa de Gutiérrez Tello y el Consulado. La red de receptorías era la siguiente:

\begin{tabular}{|l|l|}
\hline \multicolumn{1}{|c|}{ Receptoría } & \multicolumn{1}{c|}{ Puertos } \\
\hline Sevilla & -Sevilla \\
\hline Cádiz & -Cádiz \\
& - Puerto Real \\
& - Conil \\
& - Vejer \\
\hline Málaga & - Málaga \\
& - Marbella \\
& - Estepona \\
\hline El Puerto de Sta. M. ${ }^{\text {a }}$ & -El Puerto de Sta. M. ${ }^{\text {a }}$ \\
\hline Sanlúcar de Barrameda & - Sanlúcar de Barrameda \\
\hline Moguer & - Moguer \\
& - San Juan del Puerto \\
& - Palos de la Frontera \\
\hline Huelva & - Huelva \\
& - Gibraleón \\
& - Aljaraque \\
\hline Jerez & -Jerez de la Frontera \\
\hline Rota & - Rota \\
& -Chipiona \\
\hline Ayamonte & - Ayamonte \\
& - La Redondela \\
\hline Lepe & - Lepe \\
& - San Miguel \\
& - El Terrón \\
& - Cartaya \\
\hline Gibraltar & - Gibraltar \\
& - Tarifa \\
\hline
\end{tabular}

Fuente: AGI, Contaduría, leg. 421.

La red abarcaba una parte muy amplia del litoral andaluz, concentrándose sobre todo en puntos estratégicos para el comercio como ríos y bahías: el Guadalquivir, el entorno de Cádiz o el estuario del Tinto y el Odiel. Las actuales provincias de Huelva y Cádiz agrupaban la mayor parte de receptorías locales y regionales, aunque la central de Sevilla acumulase el mayor volumen de negocio, mientras la receptoría malagueña aglutinaba a los pocos puertos más dispersos que se integraron en esta estructura al este del estrecho de Gibraltar. 
Las receptorías fueron gobernadas por una nómina de receptores, que a su vez estuvieron avalados por fiadores que se comprometían a cubrir las posibles pérdidas ocasionadas en la gestión de los fondos. Los grandes hombres del comercio sevillano controlaron la red. Era normal que sucediera así, pues Gutiérrez Tello y los gobiernos consulares tenían la potestad para nombrar los receptores. La correspondencia del Consulado demuestra algo que, en cualquier caso, podría suponerse perfectamente sin documentación alguna: sólo nombraron personas de su confianza. La confianza era recíproca, claro está. Los receptores, que tenían libertad para designar a sus fiadores, confiaron tan delicado papel a notables cargadores a Indias, con responsabilidades en el Consulado ${ }^{42}$. Como le explicaba el Consulado a Sebastián Quijada cuando lo nombró receptor de Gibraltar, «por la buena relaçión $\mathrm{q}[\mathrm{ue}]$ tenemos de la persona de V[uestra] $\mathrm{m}$ [erced] le avemos nombrado por rreçeptor de las averías» ${ }^{43}$. Una red de amistad controló la trama institucional montada por la Monarquía ${ }^{44}$.

La estructura militar ${ }^{45}$ se componía de un cuerpo de oficiales, militares, marineros y remeros, a cuyo frente se encontraba el mítico marino don Álvaro de Bazán. Felipe II lo nombró capitán general de la armada pocos meses después de la aprobación del asiento. Su capitanía general le obligaba a regir las galeras en la navegación y la guerra, tomar las muestras y alardes del personal a bordo, ordenar el pago de los salarios y administrar justicia en primera instancia ${ }^{46}$. Bazán se incorporó de inmediato a su puesto y lo ejerció continuadamente, excepto durante algunos meses de 1563 en los que sirvió en la defensa de Orán con parte de sus galeras ${ }^{47}$. En ese breve intervalo, y

42 Lorenzo Sanz, 1986, I, capítulos 7 y 8.

43 AGI, Consulados, lib. 48, fol. 190v.

44 Ibidem, sobre todo folios $186 \mathrm{v}-187 \mathrm{r}$ y $188 \mathrm{v}-189 \mathrm{v}$.

45 Este artículo trata con menos detalle la estructura militar de la armada que la estructura fiscal que la sostuvo. Este desequilibrio obedece a dos razones: 1) la estructura fiscal de estas galeras, regidas por un sistema de averías, fue extremadamente original respecto a las de otras, mientras que la estructura militar fue completamente convencional y 2) las fuentes del Archivo de Indias obligan a ello, pues inciden mucho más en lo fiscal que en lo militar. Es posible que los documentos adecuados para profundizar en la estructura naval se encuentren en el Archivo General de Simancas, aunque Eufemio Lorenzo Sanz ya investigase allí en los fondos de Estado y Consejo y Juntas de Hacienda con escasos resultados. Sin embargo, la investigación futura entre los fondos de Guerra Antigua deparará, muy probablemente, mejores resultados.

46 Título de capitán general para Álvaro de Bazán, Alcalá de Henares, 8 de mayo de 1562, AGI, Contaduría, leg. 417, s.f. Sobre la jurisdicción de los capitanes generales de galeras, Lomas Cortés, 2012.

47 Real cédula, Madrid, 28 de abril de 1563, AGI, Contaduría, leg. 417, s.f. 
por recomendación suya, su hermano Alonso permaneció al frente de lo que quedaba de la escuadra, en calidad de capitán general interino ${ }^{48}$.

Bazán tuvo que trabajar con un equipo directivo formado por el pagador, el contador y el proveedor ${ }^{49}$, los llamados «oficiales de la pluma» $»^{50}$. Como pagador fue escogido Pedro de Jerez Godoy, cuya función consistía en recibir todo el dinero que le llegase por orden del prior y cónsules de la Universidad de Mercaderes para gastarlos y distribuirlos en los salarios del personal y en todas las necesidades que tuvieran las galeras. La proveeduría de la armada recayó sobre Antonio Jiménez, que tuvo a su cargo comprar los bastimentos que las galeras requiriesen, preferentemente en Andalucía o, en caso de no ser posible, en otros distritos de la Monarquía. Debía hacerlo a un precio justo en el mercado, aunque no le faltaba poder real para embargar posesiones a sus dueños si fuese preciso. Finalmente, Francisco Osorio, vecino de El Puerto de Santa María, se encargó de la contaduría. Su misión era, evidentemente, llevar las cuentas, tener al día «libros quenta» que sirviesen para garantizar que todo estaba en regla: la administración de los fondos efectuada por Jerez Godoy y Jiménez, los efectivos humanos, el estado de la artillería, la cantidad de las provisiones... ${ }^{51}$

Este equipo gobernó y gestionó una armada cuyos efectivos no parecen haber diferido mucho de la planificación inicial. No conociéndose ninguna plana general, resulta casi imposible ofrecer una visión precisa de su evolución ${ }^{52}$. Entre los pagos de 1562 sólo se mencionan cinco galeras: la Capitana, la Patrona, la Española, la Francesa y la San Pablo; pero en 1563 se les añadieron otras dos: la Porfiada y la San Juan. Estas siete conformaron la escuadra inicial, aunque con el paso del tiempo algunas fueron retiradas y sustituidas por otras que empiezan a mencionarse después, como la Soberana o la Mendoza. Su base de operaciones y lugar de invernada se encontraba en El Puerto de Santa María, aunque algunos veranos como el del 64 se optó por establecerse en Cataluña, buscando quizás climas algo más benignos. Dentro de ellas se movía un microcosmos humano de enorme riqueza: los forzados,

48 Título de capitán general para Alonso de Bazán, Madrid, 29 de abril de 1563, Ibidem.

49 Felipe II dictó unas instrucciones comunes para Bazán y estos oficiales, que desarrollaban las indicaciones de sus respectivos títulos: Ibidem; real cédula para los oficiales de la armada, Madrid, 13 de octubre de 1562.

50 Goodman, 1997: 231.

51 Todos los títulos en AGI, Contaduría, leg. 417, s.f., con fecha en Madrid, 17 de julio de 1562. Esta división de tareas era característica de las armadas de galeras. Véase al respecto Marchena Giménez, 2010: 121-139.

52 Lo Basso, 2003: 40-41 también encontró dificultades para cuantificar el cuerpo de galeras de la República de Venecia durante el siglo XVI. 
que tendían a huir en busca de libertad; los remeros de buena boya, que cobraban un salario mensual de un ducado ${ }^{53}$; los oficiales de marina, como los capitanes, los cómitres o los patrones; los soldados, que ganaban dos escudos mensuales; alguaciles, escribanos, capellanes... 54

En resumidas cuentas, la armada y su avería generaron una estructura bicéfala habitual en las escuadras de galeras españolas. Al frente de la recaudación de la avería se encontraba la diputación formada por Gutiérrez Tello y el Consulado y en cabeza del gobierno militar estaba don Álvaro de Bazán. Las órdenes de la diputación eran ejecutadas por la red de receptores, que recaudaba la avería desde los puertos integrados en la trama y hacía llegar el dinero desde su vértice sevillano (aunque ocasionalmente también desde la periferia) a los oficiales de la armada. Fundamentalmente, al pagador, que efectuaba la mayoría de los pagos directos, aunque también transfería algunos fondos a la proveeduría, siempre bajo el control de la contaduría. Todo para que los barcos estuvieran bien pertrechados, con la gente de mar, guerra y remo preparada para seguir las órdenes de Álvaro de Bazán en la misión común de defender las aguas contra posibles ataques norteafricanos y asegurar el tránsito de mercancías y metales preciosos.

El sistema funcionó razonablemente bien y las galeras prestaron un servicio que parece haber sido competente ${ }^{55}$. Las galeras patrullaron la costa y además algunas de ellas fueron divertidas en las jornadas más relevantes de aquel tiempo: Orán ${ }^{56}$, Vélez de la Gomera y, finalmente, Malta. Sin embargo, la gestión de los fondos recibió muchas críticas en duros procesos auditores que llevaron a los tribunales a muchos de estos oficiales. Poco después de recibir la provisión real, la diputación de gobierno determinó que la avería se cobraría a partir de un tipo del $00^{\prime} 75 \%{ }^{57}$. Pueden reconstruirse algunas cifras de recaudación y gasto hasta los primeros meses de $1564^{58}$. El cómputo glo-

53 El estudio más completo de los remeros de galeras en Lo Basso, 2003.

54 AGI, Contaduría, leg. 417.

55 A pesar de que muchas de ellas eran viejas y se planteó en 1564 la necesidad de sustituir algunas de ellas: consulta del Consejo de Indias, Madrid, 21 de febrero de 1564, AGI, IG, leg. 738, n. ${ }^{\circ} 70$.

56 Para acudir a Orán fueron escogidas las galeras Capitana, Patrona, San Juan y San Pablo. Las sustituyó temporalmente una flota de cinco galeotas de las que se mencionan individualmente cuatro: Santiago el Viejo, Santiago el Nuevo, La Victoria y San Román: AGI, Contaduría, leg. 417.

57 Acuerdo, Sevilla, 9 de mayo de 1562, Ibidem, leg. 421, fol. 86.

58 La fecha coincide con la comisión de Domingo de Gamarra, que se estudia en el epígrafe siguiente. Gamarra copió (y revisó) las cifras de los libros de cuentas originales, que hasta el día no han sido hallados. Por esa razón, es difícil continuar la reconstrucción cuantitativa más allá del fin de la comisión. 
bal de los cargos realizados a Juan Gutiérrez Tello y los sucesivos gobiernos consulares arrojan los siguientes datos hasta el 17 de abril:

\begin{tabular}{|c|c|c|r|r|}
\hline Período & Avería Sevilla & Avería puertos & Aportaciones & \multicolumn{1}{c|}{ Total } \\
\hline 1562 & 3.588 .848 & 975.337 & 3.720 .967 & 8.285 .152 \\
\hline 1563 & 15.962 .690 & 2.144 .544 & 13.432 .906 & 31.540 .140 \\
\hline 1564 & 4.577 .157 & 1.654 .593 & 0 & 6.231 .750 \\
\hline $1562-64$ & 24.128 .695 & 4.774 .474 & 17.153 .873 & 46.057 .042 \\
\hline
\end{tabular}

Fuente: AGI, Contaduría, leg. 421.

Como puede observarse, la recaudación completa ascendió a 46.057 .042 maravedíes, a los que pueden sumarse una nueva contabilización efectuada a mediados junio de 5.856.441 maravedíes. En total, 51.913.483 maravedíes, recaudados en un período de aproximadamente dos años. Tomando como referencia la primera muestra efectuada en abril, que se entiende suficientemente significativa, puede observarse en los distintos ejercicios anuales y en el período completo que la parte del león correspondió a la avería de la capital y a las aportaciones externas. En 1562 la avería de Sevilla significó el $43^{\prime} 3 \%$ de toda la recaudación y las aportaciones externas el 44'9\% y en 1563 representaron respectivamente el $50^{\prime} 6 \%$ y el $42^{\prime} 5$, aunque en 1564 , al no registrarse aportaciones externas, la avería hispalense alcanzó el 73'4\%. Por el contrario, la avería de puertos no supuso más que el $11{ }^{\prime} 8 \%$ en 1562 , el 6' $8 \%$ en 1563 y sólo en 1564 la desaparición de las aportaciones externas le permitió llegar al $26{ }^{\prime} 5 \%$. En todo el período completo, la avería sevillana significó el $52^{\prime} 4 \%$, la avería de los puertos el $10{ }^{\prime} 4 \%$ y las aportaciones externas el $37 \cdot 2 \%$.

La preeminencia fiscal de Sevilla no puede sorprender, porque era un reflejo de su extraordinaria vitalidad como emporio mercantil. Corrían los días del auténtico monopolio sevillano, aquellos en los que la urbe andaluza era realmente una de las mayores capitales del comercio internacional europeo ${ }^{59}$. Sin embargo, el crecimiento continuo de la actividad comercial no fue suficiente para financiar la armada de galeras. Cabe ver aquí, posiblemente, un eco de los conflictos habidos durante la implantación de la nueva avería. Para que el sistema hubiese sido autosuficiente económicamente, habría sido necesario elevar la tasa de exacción fiscal, situada en el 0'75\%. Presumiblemente,

59 Domínguez Ortiz, 1991. Chaunu, 1983. Morales Padrón, 1977. Núñez Roldán, 2004. Entre tantas otras obras que resaltan el esplendor de Sevilla en el siglo XVI. 


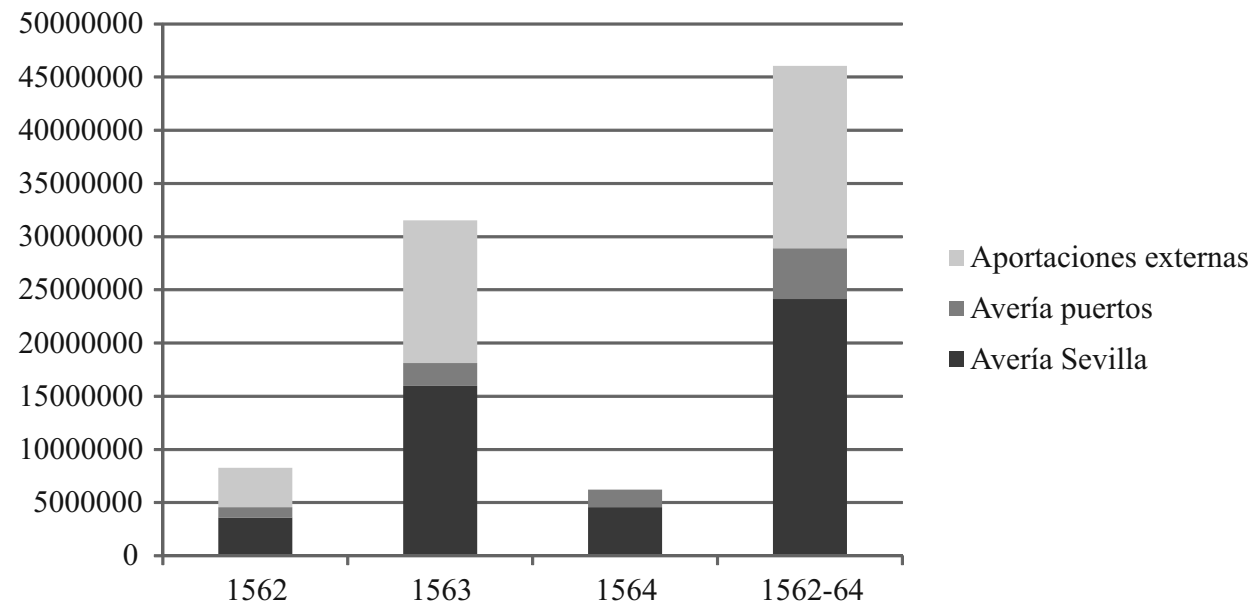

habría sido posible, pero habría vuelto a exaltar la animadversión contra la gabela, cuyo importe venía a sumarse al de los crecientes derechos y servicios impuestos por Felipe II a sus súbditos, que no eran pequeños. Si así fue, la solución sólo puede calificarse de medianamente satisfactoria. Ciertamente, se pudieron recabar aportaciones externas suficientes para satisfacer los pagos inmediatos, pero éstas no consistieron sino en préstamos realizados por el rey y diversos particulares. No eran regalos; habría que devolverlos puntualmente algún día. A la larga, el sistema no estaba haciendo otra cosa que endeudarse y lo hacía además a marchas forzadas, puesto que los préstamos suponían una aportación prácticamente equiparable a la de la avería sevillana ${ }^{60}$. Sólo el hecho de que, cuando se tomaron las cuentas a principios de 1564, no se hubiese acudido aún a este tipo de expedientes disimula un poco esta paridad en el cómputo global ${ }^{61}$.

La pieza más débil del sistema eran los llamados «puertos», es decir, todos aquellos puntos de recaudación diferentes a Sevilla. Una relación específica,

60 Lorenzo Sanz, 1986, II: 353, n. ${ }^{\circ} 38$ resalta los apuros económicos de la avería y su tendencia constante al endeudamiento. Sin embargo, fue relativamente fácil solucionar este problema, porque las deudas se saldaron a través del servicio de estas galeras en frentes diferentes de aquel para el que fueron creados, es decir en las famosas jornadas de Orán (1563), Vélez de la Gomera (1564) y Malta (1565), según se reconoce en el segundo asiento de la armada, firmado en 1566. Véase infra nota 68.

${ }^{61}$ Los problemas de déficit y endeudamiento fueron frecuentes en las escuadras de galeras: Guilmartin, 1974: 95-123. 
que cubre un arco temporal algo diferente a la muestra completa estudiada, revela los siguientes índices simultáneos de recaudación en dichas plazas:

\begin{tabular}{|c|c|c|}
\hline Receptoría & Cobro avería & $\%$ \\
\hline Cádiz & 3.334 .283 & $56^{\prime} 6$ \\
\hline Málaga & 568.235 & $9 ' 6$ \\
\hline El Puerto & 168.855 & 299 \\
\hline Sanlúcar & 572.783 & 9'7 \\
\hline Moguer & 163.312 & 2,8 \\
\hline Huelva & 59.797 & $1^{\prime} 0$ \\
\hline Jerez & 631.489 & $10^{\prime} 7$ \\
\hline Rota & 33.486 & $0{ }^{\prime} 6$ \\
\hline Ayamonte & 123.615 & $2 ’ 0$ \\
\hline Lepe & 69.725 & $1 ’ 2$ \\
\hline Gibraltar & 169.889 & $2 \prime 9$ \\
\hline
\end{tabular}

Fuente: AGI, Contaduría, leg. 421, fols. 112r-113r.

Como era de esperar, los mayores porcentajes dentro del grupo de los puertos correspondían a Cádiz. Todavía se encontraba lejos de ser aquel punto dominante del comercio colonial que llegaría a ser más de un siglo después, pero ya representaba más de la mitad de lo que se recaudaba en todo el conjunto de los puertos. A bastante distancia se encontraban Jerez de la Frontera, Sanlúcar de Barrameda y Málaga con su distrito, capaces de porcentajes que oscilaban alrededor del 10\%. Finalmente, las cantidades menos elevadas se localizaban en las villas de la actual provincia de Huelva. Aquellas tierras, protagonistas del Descubrimiento, quedaron relegadas después en la estructura del comercio colonial ${ }^{62}$.

Toda esta recaudación se invirtió en financiar las galeras de don Álvaro de Bazán. No es fácil seguirle el rastro al dinero, pero pueden reconocerse con algún grado de aproximación los movimientos principales. Las cuentas de descargo de la avería reflejan que, por orden de la diputación de gobierno, el receptor Juan Gallardo invirtió una parte relativamente pequeña en pagos directos y depositó la mayor parte de las sumas en manos de Pedro de Jerez Godoy, pagador de la armada. Jerez Godoy manejó cantidades realmente importantes $\mathrm{y}$, de hecho, él mismo fue sometido a una exhaustiva supervisión

62 González Cruz, 2012. 
de cuentas efectuada por el licenciado Alejo Salgado Correa ${ }^{63}$. El cargo de la pagaduría reconstruido por Salgado Correa revela que, en un período comprendido fundamentalmente entre 1562 y 1565 (con algunos pagos también en 1566), la institución recibió la cantidad de 68.195.810 maravedíes, procedentes de la red de receptorías y de otras fuentes ocasionales, más otros ingresos en especie ${ }^{64}$. El sumario de la data ofrece a su vez una panorámica de los gastos en los que se emplearon estos ingresos ${ }^{65}$. Las cifras permiten comprobar que la pagaduría abonó directamente a proveedores particulares o bien delegó sumas en el proveedor oficial, Antonio Jiménez, que compró con ellas otros bastimentos y vituallas ${ }^{66}$.

Estos pagos dejan entrever también la importancia que las estructuras militares de la Monarquía tuvieron sobre las economías regionales, en este caso la andaluza. Hubo hombres que recibieron su salario como marinos o como soldados y agricultores y ganaderos que colocaron parte de su producción para alimentarlos y atenderlos, así como artesanos y profesionales de variados ramos: boticarios, carpinteros, bizcocheros, bodegueros, herreros... Excepto las galeras, algunas de las cuales provenían de Denia, y algunas armas compradas en Cartagena, casi todos los demás productos provenían de las localidades andaluzas en las que la armada tuvo su campo de operaciones. Por tanto, si bien muchos tuvieron derecho a protestar por el incremento fiscal que suponía la implantación de la avería de galeras, no es menos cierto que a otros les sobraron razones para felicitarse por las inversiones oficiales, las oportunidades de negocio y el incremento del consumo que generaba el apresto de una armada como la que gobernó Bazán ${ }^{67}$.

63 Título de comisión al licenciado Salgado Correa, Madrid, 3 de marzo de 1573, AGI, IG, leg. 1.956, lib. 1, folios, 54r-59v. Salgado era entonces asesor de la Casa de la Contratación, es decir, el antecedente de los futuros jueces oficiales: AGI, Contratación, leg. 5.784, lib.1, folios 98-99. Véanse al respecto Schäfer, 2003, I: 367 y Trueba, 1988.

64 Seis pliegos de cargo, Sevilla, 1573, AGI, Contaduría, leg. 417, s.f.

65184 pliegos de data, Sevilla, 1573, Ibidem.

6657 pliegos de cargos a Antonio Jiménez, s.f., Ibidem.

67 En la actualidad, se encuentra en preparación un trabajo referido al impacto económico de las armadas de Indias sobre los sectores productivos de Andalucía y, en menor medida, de otras regiones. 
La COMisión de Domingo de Gamarra, El SEgundo ASIENTo y LA CRISIS DEL SISTEMA

Todo este movimiento de dinero era complejo y necesitaba una supervisión. Un comisario real se encargó de la labor ${ }^{68}$, Domingo de Gamarra, que llegó a Sevilla en 1564. ${ }^{69}$. El objetivo de la comisión era determinar cómo y en qué se habían gastado los fondos de la avería, investigar la actuación de todos los receptores, averiguar cuál había sido la recaudación en cada uno de los puertos, rastrear posibles fraudes, revisar que los procedimientos hubiesen sido correctos y analizar el sistema en general. Gamarra tendría que estudiar si existían medios para financiar las galeras preferibles a la avería y, finalmente, enviar toda la documentación que generasen sus pesquisas a Madrid, a fin de que fuese estudiada en el Consejo de Indias ${ }^{70}$. En resumidas cuentas, realizar una auditoría completa, en la que no quedase nada por escudriñar.

Las investigaciones de Gamarra afectaron a casi todos los implicados en la gestión de la avería, desde los miembros de la diputación de gobierno hasta los receptores y sus fiadores. Los aspectos más destacables fueron dos: el hallazgo de un alcance en las cuentas y la detección de variadas corruptelas procedimentales. Respecto a lo primero, Gamarra decidió actuar cuando tuvo seguridad de haber detectado un desfase en las cuentas de, al menos, 2.927.175 maravedíes. Fue inflexible y conminó a todos los responsables a satisfacer la parte que a cada uno correspondía de esa cantidad. Lo hizo con métodos expeditivos, condenando a pena de prisión en la cárcel de la Contratación a Juan Gutiérrez Tello (que cumplió arresto domiciliario) y la mayoría de los miembros de los gobiernos consulares entre 1562 y 1564 . Los receptores y sus fiadores también se vieron afectados en el tema del alcance, cuyas cifras no dejaban de ascender. Gamarra calculó a Juan Gallardo, receptor en Sevilla, un alcance de 2.786.109 maravedís, a Pedro del Castillo, receptor en Cádiz, otro de 464.169 y a Pedro Bernal de Espino, titular de la receptoría jerezana, 185.551. Las consecuencias no se hicieron esperar y, por supuesto, fueron más sonadas en Sevilla que en ningún otro lugar. Gallardo perdió su oficio de receptor, en el que fue sustituido por Francisco de Torres y apresó a sus fia-

${ }^{68}$ La comisión fue una institución muy generalizada en el gobierno de la Carrera de Indias, así como en muchos otros ámbitos políticos de la Monarquía. Pardo Molero y Lomas Cortés, 2012, donde se estudian las difíciles relaciones entre comisarios y oficiales reales estables.

69 AGI, Justicia, leg. 956.

70 Real cédula, Barcelona, 11 de marzo de 1564, AGI, IG, leg. 1.966, lib. 15, folios 90r-92v. 
dores, Diego Baeza de México y Alonso de Solís, a los que obligó a satisfacer la cantidad debida. Castillo se libró de la pena por pagar inmediatamente la cantidad que se le achacaba, pero Astudillo dio también con sus huesos en la cárcel ${ }^{71}$.

Más allá de los aspectos relacionados con el alcance, Gamarra publicó una extensa acusación con quince cargos de la que se infería que los implicados en la avería no habían seguido con fidelidad las directrices especificadas por Felipe II en la provisión de 1562. La denuncia iba dirigida, sobre todo, contra Gutiérrez Tello y el Consulado, quienes, según conclusiones del ministro, habían decidido actuar a su manera en materias muy graves, aunque no contasen con permiso para hacerlo. Habían fallado en la custodia de los fondos, en el registro de las cuentas, en el avalúo de las mercancías y en la gestión diaria de los pagos, se habían extralimitado en las compras de muchos bastimentos y habían consentido negligencias a los receptores ${ }^{72}$. Poco después, los resultados de la comisión llegaron a Madrid y empezaron a estudiarse en el Consejo, que juzgó a todos los imputados por Gamarra. Se repitieron, ampliaron y reformularon los cargos contra Gutiérrez Tello, los priores y cónsules, sus escribanos y contadores y la gran mayoría de los receptores locales que cobraron la avería. Se siguió un pleito individualizado contra cada uno de ellos, algunos de los cuales se confundieron con las investigaciones que Gamarra empezó a realizar en una segunda comisión a partir de $1569^{73}$.

Por si esto fuera poco, Bazán avivó el fuego al querellarse por malversación de fondos contra el pagador Pedro de Jerez Godoy, el contador Francisco Osorio y el proveedor Antonio Jiménez ${ }^{74}$. Puede suponerse el resentimiento que toda esta situación creó entre la Universidad de Mercaderes. Contribuyó a crear un ambiente poco propicio para estabilizar la armada de galeras, en unión a la renuencia a pagar aquella segunda avería, los apuros económicos coyunturales y, finalmente, el hartazgo que acabó produciendo la diversión de las unidades hacia otros focos de lucha. Porque, para colmo de males, las galeras estuvieron más tiempo sirviendo en otros frentes que protegiendo la Carrera de Indias. Como ya se ha referido, colaboraron en el socorro de Orán de 1563, en la conquista del Peñón de Vélez en 1564 y en la defensa de Malta de 1565. Cuando tuvo noticia de que las galeras serían

71 AGI, Contaduría, leg. 421.

72 Ibidem, folios 498-500. En descargo de los diputados, puede decirse que avisaron al rey de muchos de los cambios que hicieron respecto a las órdenes de la cédula: el Consulado a Felipe II, Sevilla, 22 de mayo de 1562, AGI, Consulados, lib. 48, folios 184v-187r.

73 AGI, Justicia, leg. 956.

74 Ibidem, leg. 789, n. $^{\circ} 3$. 
utilizadas para esta última ocasión, el Consulado estalló. No supo contener su enojo ante Felipe II y protestó que

los veranos pasados después q[ue] v Magd. mandó tomar el asiento, [las galeras]
siempre an seruido a v. Magd. en las Jornadas de Orán y el Peñón de Vélez. Se a
tomado por los desta Vniuersidad con mucho sentimiento, los quales nos an hecho
istançia que supliquemos a v. Magd. sea seruido de mandar que se queden en esta
costa este verano, para que con seguridad bengan estas dos flotas de las Yndias y
las otras naos que por ellas nauegaren y se consiga el fin para que se fundaron y
si todabía v. Magd. fuere seruido y mandare que hagan la jornada, le sulicamos
mande que se declare que todo el gasto que las d[ic]has galeras hizieren en ella es
a cargo de v. Magd. y de su Rreal Hazienda, como es justo, y no de las auerías ${ }^{75}$.

El Consulado se atrevió incluso a requerir a Gutiérrez Tello que dejase de cobrar las averías, puesto que el tiempo del asiento de 1562 había terminado $\mathrm{ya}^{76}$.

El rey desoyó estos razonamientos casi desafiantes. Las galeras de Bazán colaboraron en la defensa de Malta y, por si esto no bastase, en julio llegó a Sevilla la propuesta de la Corona para rubricar un segundo asiento que alargase más todavía la vida de la avería y la armada. El Consulado se resistió con una extensa batería de agravios y problemas: las galeras eran poco efectivas, bastaba la Armada de la Carrera, los comerciantes habían acumulado pérdidas y secuestros de plata en años anteriores... ${ }^{77}$ Alonso Núñez de Badajoz y Diego Díaz Becerril, prior y cónsul del Consulado, acudieron convocados a la corte y expusieron que la armada se había creado en tiempos en los que la inseguridad costera era mucho mayor. Sin embargo, después de haberse ocupado el Peñón de Vélez de la Gomera, «que hera de donde principalmente se haçían maiores rrobos», el peligro había disminuido considerablemente, por lo que solicitaron a Felipe II que no se renovase el asiento y se derogase la avería.

No eran malos argumentos, pero el Gobierno no atendió los deseos del Consulado y le impuso el segundo asiento, que se legalizó con fecha de 26 de marzo de 1566. Según aquel nuevo contrato, el comercio debería seguir

75 El Consulado a Felipe II, Sevilla, 13 de abril de 1565, AGI, IG, leg. 1.093, n. 250. Lorenzo Sanz, 1986, II: 353, cita otras cartas del Consulado fechadas en 1565 y conservadas en AGS, Estado, leg. 144.

76 Consulta del Consejo de Indias, Madrid, 11 de septiembre de 1565, AGI, IG, leg. 738, n. ${ }^{\circ}$ 79. Tello no le siguió el juego al Consulado y escribió a la Corte, donde evidentemente se desaprobó el intento.

77 Estos argumentos se contienen en cartas de la Casa y el Consulado conservadas en AGS, Estado, leg. 145 y estudiadas en Lorenzo Sanz, 1986, II: 353. 
financiado la armada. Se esperaba de él que aportase otros 109.000 ducados, de los que debían descontarse 29.000 que la Corona le adeudaba por la utilización de las galeras para fines diversos en las guerras del Mediterráneo. En total, los mercaderes tendrían que poner sobre la mesa la suma de 80.000 ducados, pagaderos en aquel año de 1566 y en el siguiente de 1567. Se conseguirían a través del impuesto de la avería, que no quedaría derogado, sino que tendría que renovarse, al igual que los demás puntos del asiento de 1562, que tuvieron continuidad en el de $1566^{78}$.

Esta segunda etapa de la historia de la armada es más difícil de reconstruir que la primera. No parecen conservarse grandes expedientes procedentes de comisiones, sino algunos pequeños pleitos de reducida capacidad informativa. Se diría que en cierto modo la escuadra fue languideciendo ante la escasa voluntad del Consulado por colaborar en su gestión y financiación, así como por el relativo retraimiento de la conflictividad en el Mediterráneo, que permitió a Felipe II centrarse en reprimir la rebelión de los Países Bajos en 156779. El asiento de 1566 se fijaba un plazo de vigencia indeterminado de dos o tres años. En 1567 Felipe II intentó que el Consulado siguiera implicándose en la empresa, pero esta vez no lo consiguió ${ }^{80}$. Cuando se agotase el segundo asiento, terminaría también la colaboración financiera del Consulado. Efectivamente, las relaciones de recaudación de averías finalizan sistemáticamente en junio de $1567^{81}$ y desde entonces la armada de galeras no pudo sobrevivir mucho más. Con lo recaudado hasta entonces pudo servir durante el resto del año 67 y tal vez durante algún tiempo en 1568, pero es difícil que pasara de ahí. En diciembre de 1568 Felipe II encargó a Domingo de Gamarra una segunda comisión que no era sino la continuación de la primera que tuvo en 156482 . En la documentación de aviso que se remitió a los receptores se hablaba de la avería como algo ya acabado ${ }^{83}$. La cédula que recibieron las autoridades locales para que colaborasen con el comisario, fechada en 1569, se expresaba en los mismos términos respecto a «las galeras de que era capitán general don Álvaro Baçán» ${ }^{84} .1568$ parece haber sido el límite cronoló-

\footnotetext{
78 Real cédula, Madrid, 26 de marzo de 1566, AGI, Contaduría, leg. 417.

79 Parker, 1986: 34.

80 Lorenzo Sanz, 1986, II: 353- 354, una vez más basado en documentación simanquina: AGS, Estado, leg. 149, números 220 y 223.

${ }^{81}$ AGI, Justicia, leg. 956. Como se informó en el puerto de Tarifa, «en junio del d[ic]ho año hasta siete días dél, que se suspendió la cobrança de la d[ic]ha av[erí]. ${ }^{\mathrm{a}}{ } \gg$.

82 AGI, IG, leg. 1.967, folios 78v-79r; real cédula, Madrid, 19 de diciembre de 1568. Los pleitos subsiguientes en AGI, Justicia, leg. 803, n. ${ }^{\circ} 1$ y Justicia, leg. 956.

${ }^{83}$ AGI, IG, leg. 1967, lib. 17, folios 75v y ss.

84 AGI, Justicia, leg. 956.
} 
gico de la armada de galeras. Con toda seguridad dejó de estar operativa antes de 1570, al menos como escuadra financiada por una avería específica gestionada por el Consulado.

\section{CONCLUSIÓN}

La década de 1560 fue un período de intensa reorganización de la Carrera de Indias, gracias a la acción de dos grandes protagonistas, la Corona y el Consulado. El retorno de Felipe II a Castilla en 1559 señaló la fecha en la cual los recursos económicos españoles se convirtieron definitivamente en el principal sostén material del imperialismo habsbúrgico. Por tanto, no puede extrañar que el Gobierno aceptase muchas de las propuestas destinadas a proteger el tesoro americano, procedentes fundamentalmente del mundo mercantil hispalense. A petición del Consulado se estableció en 1561 la obligatoriedad de que todas las naos de la Carrera viajasen en conserva, dentro de dos flotas anuales protegidas con capitana y almiranta. Evidentemente, la sistematización de las flotas requería también la sistematización de sus sistemas defensivos, que hasta aquel momento habían consistido en una sucesión de armadas pagadas por avería que protegían los mercantes entre las Azores y la península Ibérica.

Para los empresarios implicados en el comercio colonial, pronto se hizo evidente que la principal amenaza corsaria provenía entonces del Mediterráneo, donde después del desastre de Djerba menudearon los ataques contra barcos españoles. Las naos procedentes de América eran una de las presas más ambicionadas, a causa de la proverbial riqueza que trasladaban. En Sevilla no tardó en comprenderse que la provisión de 1561 no legislaba todos los aspectos necesarios para garantizar la seguridad del transporte marítimo y se solicitaron nuevas disposiciones complementarias. Se pidió a la Corona una nueva armada guardacostas de Andalucía, materializada en una armada de ocho galeras que anulase el peligro procedente de África. Felipe II accedió y mediante real provisión de 1562 decretó la creación de una escuadra que demostraba el carácter prioritario que se otorgó al corso turco-berberisco. $\mathrm{Al}$ menos, tan importante como al corso francés, si no más.

La tesis de que la intensa actividad organizativa de los años 60 tiene mucho que ver con la conflictividad del frente mediterráneo halla un respaldo decisivo en la documentación preparatoria de la provisión del $62 \mathrm{y}$, tras la aprobación monárquica, en la documentación oficial. La provisión de 1562 dejó constancia de que, sin olvidar el peligro que representaban otras naciones 
europeas, el estímulo principal para la creación de la armada de galeras fue el corso turco-berberisco:

Los daños que cosarios an hecho en la costa de Andaluzía e la nueua que se tiene de las galeras y fustas q[ue] el alcayde de Véles de la Gomera, enemigo de $\mathrm{n}$ [uest]ra santa fe católica, tiene armadas con yntento de andar por el estrecho, estando tan cerca como está a hazer el daño que pudiere y el armada que ay en Argel y las galeotas y fustas que se tiene notiçia que están en Alarache e Tetuán e los cosarios que al presente andan en el cabo de San Viçente ${ }^{85} \ldots$

La claridad con la que se expresa la cédula se repite en los títulos de la oficialidad de la armada, publicados pocos meses después. El que recibió don Álvaro de Bazán dice:

Los daños que estos años pasados an resçebido el prior y cónsules de la Vniversidad de los Mercaderes de la cibdad de Sevilla y otros tratantes ansý en las Yndias como en levante e poniente e la nueva que al presente se tiene de las galeras y fustas que el all[ca]id[e] de Véles de la Gomera tiene formadas con yntento de andar por el estrecho de Gibraltar, por estar como está tan çerca para fazer el daño que pudiere, e del armada que ay en Argel e las galeotas e fustas de Alarache e Çalé e Tetuán e de los cosarios que andan en el cabo de San Biçente y entendiendo quel prinçipal remedio para asigurar aquellas costas e las naos que se esperan de las Yndias y oviar los daños que los $\mathrm{d}[$ ic] hos cosarios e moros pueden fazer es armarse algunas galeras que anden por el d[ic]ho estrecho fasta Málaga y el cabo de San Biçente ${ }^{86}$.

Finalmente, también los supervisores externos de la armada tuvieron claro cuáles habían sido los orígenes de la escuadra. El título de la comisión de Gamarra se explaya ampliamente en ese sentido:

Aviendo entendido los daños q[ue] cosarios avían hecho en la costa de la Andaluzía y la nueua $\mathrm{q}[\mathrm{ue}]$ se tenía de las galeras y fustas de moros q[ue] tenían armadas con yntento de andar por el estrecho [de Gibraltar] y los cosarios q[ue] andauan por el cabo de San Viçente, a supp[licaci]ón del prior y cónsules de la Vniversidad de los Mercaderes de la ciudad de Seui[1la]. acordamos para asegurar aquellos mares y las naos q[ue] se esperauan de las Yndias y oviar los daños q[ue] los dos cosarios turcos y moros podían hazer de mandar q[ue] anduuiesen ocho galeras y vna fregata por la costa del estrecho de Gibraltar hasta Málaga y cabo de San Viçente ${ }^{87}$.

85 Ibidem, leg, 1.150, n. ${ }^{\circ}$ 1, r. 2, s.f.

86 AGI, Contaduría, leg. 417, s.f.

87 Ibidem, leg. 421, fol. 68. 
Los focos de amenaza marítima a comienzos de la década de 1560 se encontraban bien localizados. Apuntaban sobre todo hacia la costa sur del Mediterráneo, hacia ese espacio islámico que en aquellos años se encontraba en plena ebullición contra el poder cristiano. No se dejaba de tener presente -insístase en ello para no incurrir en la simplificación contraria- a los corsarios de Francia e Inglaterra, pero se temían más que ninguna otra cosa los ataques provenientes de las plazas y estados norteafricanos integrados en la órbita del Imperio Otomano. Argel, Peñón de Vélez de la Gomera, Larache, Tetuán, Salé... ahí estaba la geografía enemiga, que en última instancia miraba hacia Estambul y el poder osmanlí.

La armada de galeras desapareció hacia 1568 , a causa de las diferencias entre la Monarquía y el comercio sevillano. Ocurrió un poco antes de lo que hubiera sido deseable en caso de haber funcionado correctamente. Al Mediterráneo aún le quedaban algunos años de protagonismo en la vida europea. En 1570 Argel ocupó Túnez y el Turco, Chipre; en 1571 tuvo lugar la batalla de Lepanto; en 1573 España recuperó Túnez, pero en 1574 los turcos recuperaron definitivamente la plaza ${ }^{88}$. Ciertamente, este escenario internacional estaba llamado a desaparecer. Desde mediados de los 70 se relajó el choque entre los imperios que se disputaban el mar interior. El Imperio Otomano se replegó hacia el este para hacer frente a la amenaza expansiva de la Persia Safawi y la Monarquía Hispánica se volcó hacia el Atlántico y la Europea del Norte, una vez más hacia los conflictos internos de la Europa cristiana. En 1577 la Monarquía y el Imperio Otomano firmaron el primero de una duradera secuencia de tratados de paz, que cambió la faz de la política española.

De no haber sucumbido a sus problemas internos, habría sido difícil que la armada de galeras sobreviviese al retraimiento del Mediterráneo y la definitiva primacía del Atlántico ${ }^{89}$. Los documentos fundamentales de la navegación atlántica reflejan aquel cambio de tendencia. Según se recordará, la provisión de 1561 no estableció precisiones geográficas y legisló para proteger el comercio colonial de la amenaza del corso. Sin más distinciones. Las ordenanzas del año 1564, todavía dentro de aquellos «seis últimos años de la supremacía turca», se reafirmaron en esta indeterminación geográfica, justificando su articulado «por obuiar los daños que los cossarios podian hazer» ${ }^{90}$. Sin embargo, las nuevas ordenanzas de flotas que se publicaron en 1582 tenían

\footnotetext{
88 Parker, 1986: 34-35.

89 Las demás escuadras de galeras también tendieron a la disminución a lo largo de este proceso: Thompson, 1981: 219. Lo Basso, 2003: 314.

90 Encinas, 1945, IV: 130-133.
} 
ya un espíritu diferente. Su preocupación eran los «cosarios hereges» ${ }^{91}$. Evidentemente, la expresión remite a Inglaterra, a las Provincias Unidas, a los hugonotes franceses. No al Islam. Era ya otro tiempo, distinto de aquel en el que la Sublime Puerta había estremecido a cuantos entregaban sus riquezas al cobijo inseguro del mar.

\section{BiBLIOGRAFÍA}

Chakib, Benafri, "La posición de la sublime puerta y de la regencia de Argel ante a rebelión de los moriscos granadinos (1568-1570): entre esperanza y decepción", Áreas. Revista Internacional de Ciencias Sociales, 30 (Murcia, 2011): 141-146.

Braudel, Fernand, El Mediterráneo y el mundo mediterráneo en la época de Felipe II, 2 vols., México, FCE, 2005 [1949].

Castro y Bravo, Federico de, Las naos españolas en la Carrera de las Indias. Armadas y flotas en la segunda mitad del siglo XVI, Madrid, Editorial Voluntad, 1927.

Huguette y Chaunu, Pierre, Séville et l'Atlantique. Tome III. Le trafic, de 1561 a 1595, París, Armand Colin, 1955.

Chaunu, Pierre, Sevilla y América. Siglos XVI-XVII, Sevilla, Universidad, 1983.

Domínguez Ortiz, Antonio, Orto y ocaso de Sevilla, Sevilla, Universidad, 1991 [1946].

Encinas, Diego de, Cedulario Indiano, 5 vols., [1596], edición, estudio e índices de Alfonso García Gallo, Madrid, Cultura Hispánica, 1945-47.

Favarò, Valentina, La modernizzazione militare nella Sicilia di Filippo II, Palermo, Associazione Mediterranea, 2009.

Fenicia, Giulio, Il regno di Napoli e la difesa del Mediterraneo nell età di Filippo II (1556-1598), Bari, Cacucci, 2003.

García-Baquero González, Antonio, La Carrera de Indias: suma de la contratación y océano de negocios, Sevilla, Algaida, 1992.

García Hernán, Enrique, La Armada española en la Monarquía de Felipe II y la defensa del Mediterráneo, Madrid, Tempo, 1995.

Glete, Jan, War and the State in Early Modern Europe. Spain, the Dutch Republic and Sweden as Fiscal-Military States, 1500-1650, Londres/Nueva York, Routledge, 2002.

91 Ibidem: 137-139. 
González Cruz, David (coord.), Descubridores de América. Colón, los marinos y los puertos, Madrid, Sílex, 2012.

Goodman, David, El poderío naval español. Historia de la armada española del siglo XVII, Barcelona, Península, 1997.

Guilmartin, John F., Gunpowder and Galleys. Changing Technology and Mediterranean Warface at Sea in the Sixteenth Century, Cambridge, University Press, 1974.

Hamilton, Earl J., El tesoro americano y la revolución de los precios en España, 1501-1650, Barcelona, Crítica, 2000 [1934].

Haring, Clarence H., Comercio y navegación entre España y las Indias en la época de los Habsburgos, México, FCE, 1979 [1918].

Hess, Andrew C., The Forgotten Frontier. A history of the Sixteenth-Century Ibero-African Frontier, Chicago, Universidad, 1978.

Iglesias Rodríguez, Juan José, La Villa de Puerto Real en la Edad Moderna (14831812), Málaga, Unicaja, 2003.

Lane, Frederic C., Venice, a Maritime Republic, Baltimore, Johns Hopkins University Press, 1973.

Lo Basso, Luca, Uomini da remo. Galee e galeotti del Mediterraneo in età moderna, Milán, Selene, 2003.

Lomas Cortés, Manuel, "Justicia y gobierno en las galeras de Felipe III", Davide Maffi (a cura di), Tra Marte e Astrea. Giustizia e giurisdizione militare nell'Europa della prima età moderna (secc. XVI-XVIII), Milán, Franco Angeli, 2012: 125-152.

Lorenzo Sanz, Eufemio, Comercio español con América en la época de Felipe II, 2 vols., Valladolid, Institución Cultural Simancas, 1986.

Marchena Giménez, José Manuel, "La vida y los hombres de las galeras de España (siglos XVI-XVII)", tesis doctoral inédita, Universidad Complutense de Madrid, 2010: 121-139, resumen de la tesis en http://eprints.ucm.es/12040/ (Fecha de consulta 26/11/2014.

Mira Caballos, Esteban, La Armada Guardacostas de Andalucía y la defensa de la Carrera de Indias (1521-1550), Sevilla/Bogotá, Muñoz Moya, 1998.

Mira Caballos, Esteban, "Controversias sobre el sistema naval con América a mediados del siglo XVI: los proyectos de Álvaro de Bazán”, Iberoamericana, 7 (Madrid, 2002): 39-57.

Mira Caballos, Esteban, "Hacia la configuración del sistema de flotas: el proyecto de navegación de Bernardino de Mendoza (1548)", Revista de Historia Naval, 81 (Madrid, 2003): 7-20.

Mira Caballos, Esteban, "Pedro Menéndez de Avilés diseñó el modelo de flotas de la Carrera de Indias", Revista de Historia Naval, 94 (Madrid, 2006): 7-24. 
Morales Padrón, Francisco, La Ciudad del Quinientos, Sevilla, Universidad, 1977.

Núñez Roldán, Francisco, La vida cotidiana en la Sevilla del Siglo de Oro, Madrid, Sílex, 2004.

Olesa Muñido, Francisco Felipe, La organización naval de los estados mediterráneos y en especial de España durante los siglos XVI y XVII, Madrid, Editorial Naval, 1968.

Pardo Molero, José Francisco, La defensa del imperio. Carlos V, Valencia y el Mediterráneo, Madrid, Museo del Prado, 2001.

Pardo Molero, José Francisco y Lomas Cortés, Manuel (coords.), Oficiales reales. Los ministros de la Monarquía Católica (siglos XVI-XVII), Valencia, Universidad, 2012.

Parker, Geoffrey, "España, sus enemigos y la Revuelta de los Países Bajos”, España y los Países Bajos, 1559-1659. Diez estudios, Rialp, Madrid, 1986: 17-51.

Rodríguez Salgado, María J., Un imperio en transición. Carlos V, Felipe II y su mundo, Barcelona, Crítica, 1992.

Salas Almela, Luis, Medina Sidonia. El poder de la aristocracia, 1580-1670, Madrid, Marcial Pons, 2008.

Schäfer, Ernst, El Consejo Real y Supremo de las Indias. Historia y organización del Consejo y de la Casa de Contratación de las Indias, Valladolid, Junta de Castilla y León/Marcial Pons, 2003 [1935].

Thompson, Irving A. A., Guerra y decadencia. Gobierno y administración en la España de los Austrias, Barcelona, Crítica, 1981.

Trueba, Eduardo, Sevilla, tribunal de océanos. Siglo XVI, Sevilla, E. Trueba, 1988.

Ulloa, Modesto, La Hacienda Real de Castilla durante el reinado de Felipe II, Madrid, FUE, 1986.

Fecha de recepción: 10 de junio de 2013.

Fecha de aceptación: 18 de diciembre de 2013. 


\section{An armada of galleys for the Career of Indies: Mediterranean and colonial trade in the times of Philip II}

This paper intends to join the reorganization of the Career of Indies in the 1560's and the "last six years of the Turkish supremacy" in the Mediterranean (1559-1565) by studying the history of an almost forgotten armada of galleys. The analyze of the documents relatives to this armada in the West Indies Archive of Seville allows to conclude that the Mediterranean war between Spain and the Ottoman Empire was one of the causes for the creation of the system of convoys in the Career.

KeY words: Hispanic Monarchy (Philip II); Ottoman Empire (16 $6^{\text {th }}$ century); Career of Indies; Mediterranean; galleys. 